\title{
Early Indian metallurgy by Paul T Craddock
}

\begin{abstract}
The volume Early Indian Metallurgy, the production of Lead, Silver and Zinc through Three Millennia in North West India, Archetype, London by PT Craddock, presents the studies carried out in several decades, since 1982, of research in three zinc, lead and silver mines in India: Zawar, Dariba and Agucha. The surveying methods, the sampling and the methods of analyses employed for the various materials are clearly illustrated and some historical notes and information on ancient literature are presented. Chapter 3 and 4 are dedicated to the history, geography and geology of the three mines. The actual investigations carried out on the mines and the recovered materials, (including wood for radiocarbon dating) are presented in den chapters 5 to 9 and are illustrated with stunning photographs and excellent drawings. Silver and lead production are discussed in chapter 10 and the production of brass and zinc in chapter 11. Chapter 12 discusses the history the Indian metallurgical industry in the $17^{\text {th }}-21^{\text {st }}$ century AD. The volume concludes discussing zinc production in various parts of the world, from Europe to China.
\end{abstract}

Keywords: ancient metallurgy, british museum, archetype, lead and silver mines, mining
Volume 2 Issue 2 - 2017

\author{
Giumlia Mair A \\ Director of AGM Archeoanalisi, Italy
}

Correspondence: Giumlia Mair A, Director of AGM Archeoanalisi, Italy, Email giumlia@yahoo.it

Received: June 07, 2017| Published: November 20, 2017

\section{Review}

The topic of the volume "Early Indian Metallurgy the production of Lead, Silver and Zinc through Three Millennia in North West India", just published by Archetype Publications in London, discusses of archaeological data and analytic results, collected in several decades of research in three zinc, lead and silver mines in India. The author of the volume is Paul T Craddock, former Head of Metallurgy in the Department of Scientific Research of the British Museum in London, a well-known scholar that in the past published several important books on topics regarding the field of ancient metallurgy.

Several chapters have been written in collaboration with other scholars. The 3rd, 4th and 5th chapters, on the historical researches on the various sites, on the geology and geography and on mining have as co-author Lalit K Gurjar \& Lynn Willies ${ }^{1}$ is co-author of the chapters on mining and on the various operations carried out in and around the mines, for example, drainage, timbering, air supply and beneficiation. The 7th chapter on the scientific examination of the samples from the different mines is the result of the efforts of several scholars: AP Middleton, CR Cartwright, K Eckstein, IC Freestone, DR Hook and ND Meeks.

On the front page the authors of the volume are given as PT Craddock as main author, with KTM Hegde, LK Gurjar and L Willies. Oddly, KTM Hegde only appears in the volume as member of the survey expedition and perhaps of the excavation, but not as co-author of any of the chapters. The date of the beginnings of large mining operations in the area of the Aravalli Hills in Rajasthan in North West Indian is the Mauryan period (4th- $2^{\text {nd }}$ century BC), but there may have been small scale workings in earlier periods as well. The mines studied for this research are three, all are located in the area of the Aravalli Hills: Zawar is located on the hills and Dariba and Agucha in the plains.

In the first chapter the author writes about the history of this research (that begun as early as 1982) and illustrates the surveying methods, the sampling and the methods of analyses employed for the various materials. Chapter 2, with the title "Early Metallurgy in the Aravalli Hills and Rajasthan", provides some very short notes on the limited knowledge we possess on Indian metallurgy of silver from Harappan times, ${ }^{2,3}$ Mohenjo Daro and Afghanistan ${ }^{4}$ and on Latin and Greek sources that discuss Indian ore deposits and trade. ${ }^{5}$ After this brief excursus on the early period, titled "Prehistory", but also covering Classical times until the 2nd century AD, the chapter jumps directly to the "Records of 19th century copper production", which is described in great detail and to sections called "Lead and Zinc", "Lead" and finally "Zinc" again. Perhaps choosing a different title for this chapter and other headings for the various paragraphs, (especially "Lead and Zinc", "Lead" and "Zinc") and subdividing the text in a different way would have helped organizing this rather messy chapter, otherwise containing useful information.

Chapter 3, written with LK Gurjar, covers the history of the three mines and describes the related monuments. At Zawar there are no early occupation remains, but some Iron Age ceramic fragments were recovered in the vicinity. ${ }^{6}$ The authors hypothesize that the Mauryian state was involved in the establishment of the large scale mining operations in the Zawar mine, where a large number of workers were employed, however no traces of occupation or architectural remains dated to periods before the 14th century AD were found. ${ }^{7}$ The Zawar mines were apparently first exploited for the production of zinc oxide to be used in medicine and only in later times as silver and zinc mines. The mining activities at the Rajpura-Dariba silver mines begun in Mauryan times, but very little is known on their early history. ${ }^{8}$ The Rampura-Agucha mines were exploited in three different phases: in the pre-Mauryan and Mauryan period (3rd century BC), in the Sunga and Kushan period (2nd century BC - 3rd century AD) and in the Gupta period (3rd-6th century AD). ${ }^{9-11}$ Chapter 4 gives an excellent overview of the geography and geology of the Aravalli Hills and discusses their mineral resources. ${ }^{12-14}$

In chapter 5 the various investigations carried out in the three mines are described in detail, with many significant and rather stunning photographs of the ancient galleries, of details such as ladders, 
wooden supports, waste heaps, pillars, wooden launders, bridges, traces of firesetting etc. The text goes through the various parts and the lodes of the three mines and discusses the diverse finds. ${ }^{15-17}$ The rich wood finds were sampled for radiocarbon dating and dates between the 9th century $\mathrm{BC}$ and the 17th century $\mathrm{AD}$ were established in Zawar, mid 2nd millennium $\mathrm{BC}$ to the mid first millennium $\mathrm{AD}$ at Rajpura-Dariba and mid to late first millennium $\mathrm{BC}$ to the 2nd century BC at Rampura-Agucha. Beside wood, some ceramics (p. 58) and even baskets (p. 79) have been salvaged. The splendid and very precise drawings of shafts, workings, arches and fireset hollows, together with the plans and sections of the mines, deserve a special mention and perfectly integrate the photographic documentation. The reconstructions of mining scenes and operations are less impressive.

Chapter 6 elucidates the surveys and excavations of the surface sites: smelting remains, zinc distillation plants, furnaces, retorts, cupellation remains, tuyeres, crucibles, cupels and all sorts of vitrified residues and related buildings are listed and discussed in great detail. ${ }^{18}$ The photographic documentation is excellent, but, certainly because of the large number of illustrations, some of the photos had, regrettably, to be quite reduced in size. Chapter 7 presents the scientific examination with very exhaustive data on slags, furnace remains, retorts for the distillation of zinc, the remains of cupellation, refractories, various residues, such as fillers and ashes, remains of lead smelting identified on ceramic materials, as well as minerals and metals recovered on the sites, including the production of bronze alloys at Dariba, where silver and lead were smelted. ${ }^{19-21}$ Aim of the analyses were the identification of the ores and raw materials, the kind of preparation processes, the reconstruction of the metallurgical processes and determination of their temperatures and duration, the kind of materials produced, the chronological and spatial evolution and changes in the processes, the recycling of the materials. The fascinating and very complete documentation will be extremely useful for any researcher studying similar materials. The scientific language is kept as simple as possible and it is easily understandable. The various types of slag, furnace lining, zinc-rich crusts, ashes etc. are accurately described, the composition is given in tables and the materials are richly illustrated with colour photos, diagrams and micrographs.

In chapter 8 mining and beneficiation are illustrated by following the evolution of the mining activities through the centuries and discussing the evidences by comparing them with the very detailed information given in the Arthaśāstra, a text written in the 4th century BC by Kautilya, who was minister of the first Mauryan emperor Chandragupta. The Arthaśāstra describes the organization and the bureaucracy of mines, but also prospection, refining, alloying and mine administration. This important chapter describes the mining methods, haulage, tools, firesetting, timbering, ventilation, drainage and beneficiation. A striking difference from ancient Western mines is the complete lack in India of technical devices for haulage and draining, set in motion by animal- or water-power, as in the known contemporary Western counterparts. Ventilation was controlled by lighting fires under one of parallel shafts, creating thus a rising air draught, while drainage was managed by simple human labour force.

The pre-smelting preparations, such as calcining, roasting and briquetting are presented in chapter 9. A details section on the various kinds of fuel (wood, dung, charcoal, charcoal characteristics, charcoal production and supply $)^{21}$ follows. Bellows, tuyeres, hearths and furnaces are also reviewed and investigated in this essential chapter that exhaustively and competently scrutinizes the smelting processes of copper and lead.
In chapter 10 the silver and lead production of Dariba and Agucha are discussed and compared with the information given in the Arthaśāstra and with the reconstructions of cupellation hearths in ancient times in the West (for example in the Greek silver mine of Laurion, 4th - 5th century BC). Later Indian descriptions of the cupellation process and of assaying methods conclude this chapter. The production of brass and zinc are the topic of chapter 11. The author first reports on ancient mentions of brass in India, then lists early descriptions of brass production both in Indian and in Latin and Greek texts and reconstructs the cementation processes. ${ }^{6,19}$ The second part of this chapter is dedicated to the production of zinc as metal, the early brass production and finally the processes in use at Zawar. ${ }^{17}$

Chapter 12 describes the extinction and revival of the Indian metallurgical industry in the 17 th - 21st century AD and chapter 13 gives a summary and overview on Indian silver and zinc production, on Chinese zinc production and on zinc in Europe. To conclude: this volume represents an important step forward in our knowledge of metallurgy in India through the centuries, but it is also a compendium of what we know on silver and zinc metallurgy in the West. As such this excellent book is a must for any archaeometallurgical library and can be a useful tool for any scholar working on this wide field.

\section{Acknowledgements}

None.

\section{Conflict of interest}

Author declares there is no conflict of interest.

\section{References}

1. Willies L, Craddock PT, Gurjar LK, et al. Ancient lead-zinc mining in Rajasthan, India. World Archaeology. 1984;16(2):222-233.

2. Reedy CL. Himalayan Bronzes: Technology, Styles and Choices. University of Delaware Press, USA; 1997.

3. Agrawal DP, Seshadri R. The metallurgical tradition of the Harappans. In: Tripathi V, editor. Archaeometallurgy in India, Sharada Publishing House, India. p. 10-16.

4. Allchin B, Allchin FR. The Rise of Civilization in India and Pakistan. Cambridge University Press, USA; 1982.

5. Mair GA, Jeandin M, Ota K. Metal trade between Europe and Asia in classical antiquity. In: Mei J, Rehren T, editors. Metallurgy and Civilisation: Eurasia and Beyond. Archetype Publications, London; 2009. p. 35-43.

6. Kharakwal JS. Zinc Production in India. Infinity Foundation, Pentagon Press, India; 2001

7. Hooja R. A History of Rajasthan. Rupa publications: India; 2006.

8. Jain NC, Rakesh KC. Rajpura Dariba Lead-Zinc Mine. Mining Magazine. 1984;150:22-31.

9. Gandhi SM. Rampura-Agucha lead/zinc deposit. Mining Magazine. 1983;149(5):315-321.

10. Tiwari RK, Kavdia NK. Ancient mining activity around Agucha village. Man and Environment 8, India; 1984. p. 81-87.

11. Nagarch BL, Trivedi PK. A note on Agucha. Puratattva. 1981;10:106.

12. Roy AB, Nagori DK, Golani PR, et al. Structural geometry of the rock phosphate bearing Aravally rocks around Jhamarkotada Mines area, Udaipur District, Rajasthan. Indian Journal of Earth Science 7. 1980. p. 192-202. 
13. Gandhi SM. Ancient mining and metallurgy in Rajasthan. In: Deb M, editor. Crustal Evolution and Metallogeny in the Northwestern Indian Shield, Narosa Publishing House, India; 2000. p. 29-48.

14. Krishnaswamy S. India's Mineral Resources, 3rd ed. In: Sinha RK, editor. Oxford and IBH Publishing, India; 1988.

15. Willies L. Ancient lead-zinc-silver mines in Rajasthan. Mining Magazine. 1989. p. 31-35.

16. Craddock PT, Freestone IC, Gurjar LK, et al. The production of lead, silver and zinc in ancient India. In: Hauptmann A, et al. editor. Old World Archaeometallurgy, Germany; 1989. p. 51-70.

17. Hegde KTM, Craddock PT, Sonavane VH. Zinc distillation in ancient India. In: Olin JS, Blackman MJ, editors. Proceedings of the 24th International Archaeometry Symposium. Smithsonian Institution Press, USA; 1986. p. 249-258.
18. Craddock PT, Cartwright C, Eckstein K, et al. "Simple sophistication: Mauryan silver production in north west India". British Museum Technical Bulletin 7. USA; 2013. p. 79-93.

19. Craddock PT, Eckstein K. Production of brass in antiquity by direct reduction. In: Craddock PT, Lang J, editors. Mining and Metal Production through the Ages. British Museum Publications, London; 2003. p. 216-230.

20. Freestone IC, Middleton AP, Craddock PT, et al. Role of materials analysis in the reconstruction of early metal extraction technology: zinc and silver-lead smelting at Zawar, Rajasthan. In: Vandiver PB, et al. editors. Materials Issues in Art and Archaeology II. Materials Research Society, USA; 1991. p. 617-626.

21. Rehder JE. The Mastery and Uses of Fire. McGill Queen's University Press, Canada; 2000. p. 244. 